\title{
The sensitivity of Demodex canis (Acari: Demodicidae) to the essential oil of Melaleuca alternifolia - an in vitro study
}

\author{
A sensibilidade do Demodex canis (Acari: Demodicidae) ao óleo essencial de \\ Melaleuca alternifolia - um estudo in vitro \\ Rita de Cássia da Silva Machado Neves ${ }^{1,2 *}$ (1); Luciano Antunes Barros ${ }^{1,3}$; \\ Shihane Mohamad Costa Mendes ${ }^{3}$; Thalita Irineu de Souza Werneck de Assis de Amorim; ${ }^{4}$ Vany Perpétua \\ Ferraz ${ }^{5}$; Lúcia Aparecida de Fátima Mateus ${ }^{6}$; Juliana da Silva Leite ${ }^{1,2,7}$; Ana Maria Reis Ferreira ${ }^{1,2,7}$ \\ ${ }^{1}$ Área de Concentração em Clínica e Reprodução Animal, Programa de Pós-graduação em Medicina Veterinária, Faculdade de \\ Veterinária, Universidade Federal Fluminense - UFF, Niterói, RJ, Brasil \\ ${ }^{2}$ Hospital Veterinário Professor Firmino Marsico Filho, Faculdade de Veterinária, Universidade Federal Fluminense - UFF, Niterói, RJ, Brasil \\ ${ }^{3}$ Departamento de Saúde Coletiva e Saúde Pública Veterinária, Faculdade de Veterinária, Universidade Federal Fluminense - UFF, \\ Niterói, RJ, Brasil \\ ${ }^{4}$ Faculdade de Veterinária, Universidade Federal Fluminense - UFF, Niterói, RJ, Brasil \\ ${ }^{5}$ Departamento de Química, Instituto de Ciências Exatas, Universidade Federal de Minas Gerais - UFMG, Belo Horizonte, MG, Brasil \\ ${ }^{6}$ Instituto de Biociências, Universidade Federal de Mato Grosso - UFMT, Cuiabá, MT, Brasil \\ ${ }^{7}$ Departamento de Patologia e Clínica Veterinária, Faculdade de Veterinária, Universidade Federal Fluminense - UFF, Niterói, RJ, Brasil
}

How to cite: Neves RCSM, Barros LA, Mendes SMC, Amorim TISWA, Ferraz VP, Mateus LAF, et al. The sensitivity of Demodex canis (Acari: Demodicidae) to the essential oil of Melaleuca alternifolia - an in vitro study. Braz J Vet Parasitol 2020; 29(3): e005220. https://doi.org/10.1590/S1984-29612020059

\begin{abstract}
The essential oil of the Melaleuca alternifolia (Maiden \& Betche) (tea tree oil) has been effective in previous studies, in the treatment of infestation by Demodex mites in humans. The present study aimed at evaluating the in vitro acaricidal effect of this herbal medicine on Demodex canis. For the parasitological examination, samples were collected from a dog's skin and examined using optical microscopy. Only samples with intact mites and with evident movement of chelicerae and tarsi were selected. Twenty-one samples were tested with the oil, in seven different concentrations: $100 \% ; 50 \% ; 25 \% ; 12.5 \% ; 6.25 \% ; 5.0 \%$ and 3.13\%. Three samples were tested with the positive control amitraz, and three with the negative control neutral shampoo. The interval between the time the solution was added and the moment the movement of the last mite ceased defined the survival time in the sample. By comparing the times at different concentrations and controls, the results showed that the higher the concentration of the oil, the more quickly its lethal effect occurred, and that the survival times in the controls were longer than in the different concentrations of melaleuca oil.
\end{abstract}

Keywords: Dogs, mite infestations, Melaleuca alternifolia oil, acaricidal effects.

\begin{abstract}
Resumo
O óleo essencial de Melaleuca alternifolia (Maiden \& Betche) (óleo da árvore do chá) foi eficaz em estudos anteriores, no tratamento da infestação por ácaros Demodex em humanos. O presente estudo teve por objetivo avaliar o tempo do efeito acaricida, in vitro, desse fitoterápico sobre Demodex canis. Para o exame parasitológico, amostras foram coletadas da pele de um cão e examinadas por microscopia óptica. Apenas amostras com ácaros íntegros e com evidente movimentação de quelíceras e tarsos foram selecionadas. Vinte e uma amostras foram direcionadas para teste com o óleo, em sete concentrações diferentes: 100\%; 50\%; 25\%; 12,5\%; 6,25\%; 5,0\% e $3,13 \%$. Três amostras foram testadas com o controle positivo, amitraz, e três com o controle negativo, xampu neutro. O intervalo entre o momento em que a solução foi adicionada e o instante em que cessou o movimento do último ácaro definiu o tempo de sobrevivência na amostra. Os tempos nas diferentes concentrações e nos controles foram comparados. Quanto mais alta a concentração do óleo, mais rapidamente ocorreu seu efeito letal. Os tempos de sobrevivência nos controles foram maiores que nas diferentes concentrações do óleo de melaleuca.
\end{abstract}

Palavras-chave: Cão, infestação por ácaro, óleo de Melaleuca alternifolia, efeito acaricida.

Received March 16, 2020. Accepted June 08, 2020

*Corresponding author: Rita de Cássia da Silva Machado Neves. E-mail: nevesrita@id.uff.br 


\section{Introduction}

Mites of the genus Demodex are commensal on the skin of mammals (Patra et al., 2019) causing severe inflammatory skin disease when a population of these parasites exceeds the point of equilibrium. The pathogenic role of these mites is well documented in dogs, in which Demodex canis Leydig 1859 causes demodicosis (Jarmuda et al., 2012), which usually requires several months of treatment to achieve clinical resolution (Mueller et al., 2012).

For decades, in many countries, the gold-standard treatment for demodicidosis has consisted of the application of an aqueous dilution of amitraz, a product of the formamidine group (Adams, 2003). Despite its variable efficacy (Arsenović et al., 2015), it has been responsible for numerous cases of intoxication (Gortel, 2006; Barretto et al., 2017). The acaricidal activity of amitraz is based on disrupting the transmission of nerve impulses, because it is an antagonist at the octopamine receptor level (Hugnet et al., 1996; Rhodes, 2004). Systemic macrocyclic lactones, some orthodox and some off-label, such as ivermectin, doramectin, and moxidectin, subsequently became available for use as more convenient forms of treatment in veterinary medicine (Delayte et al., 2006) and continues to be used in small animal clinics, although there have been some reports of adverse reactions (Singh et al., 2011; Perego et al., 2019).

More recently, four drugs in the isoxazoline class-fluralaner, afoxolaner, sarolaner, and lotilaner-in off-label and orthodox manner, compose the therapeutic arsenal against demodicidosis (Fourie et al., 2015; Beugnet et al., 2016; Six et al., 2016; Snyder et al., 2017). Although the drugs in this new class are considered safe, some adverse reactions, such as neurological and gastrointestinal symptoms, have been reported (Rohdich et al., 2014; Gaens et al., 2019).

In the search for more effective and less toxic drugs, herbal medicines have arisen as potential alternatives, with few residual effects and a low incidence of resistance (Castro et al., 2018). Among these, essential oils constitute an appealing option because they contain a variety of volatile secondary metabolites known to play a role in plant defense mechanisms (Nazzaro et al., 2013). Tea tree oil, derived from the leaves of the Australian tea tree Melaleuca alternifolia (Maiden \& Betche, 1905), has been reported to have antibacterial properties (Neves et al., 2018; Puvača et al., 2019), anti-inflammatory properties (Caldefie-Chézet et al., 2004; Neves et al., 2018), and antiparasitic properties (Neves et al., 2013; Puvača et al., 2019; Savla et al., 2019; Zulkarnain et al., 2019).

As a rule, the International Organization for Standardization (ISO 4730:2004) and the Australian Standards Association (AS 2782-2009) require a minimum content of 30\% of terpinen-4-ol, considered the most active ingredient in exerting Demodex mite-killing effects (Tighe et al., 2013), and a maximum content of 15\% of 1,8-cineole, an undesirable allergen, in the tea tree essential oil (Silva et al., 2002; Simões et al., 2002; Walton et al., 2004; Mondello et al., 2006; Tighe et al., 2013; Malhi et al., 2017).

Despite the tea tree oil having been tested in terms of its efficacy against mites of the Demodex genus in humans (Gao et al., 2005; Savla et al., 2019), its efficacy against the etiological agent of canine mange has never been compared. Therefore, the aim of this study was to evaluate the in vitro acaricidal effect of tea tree oil on Demodex canis mites.

\section{Materials and Methods}

\section{Ethical considerations}

All procedures were performed in compliance with the Ethical Principles on Animal Experimentation established by the Brazilian Society for the Ethical Use of Laboratory Animals in Scientific Research. The study was approved by the Animal Research Ethics Committee of the Universidade Federal Fluminense (Protocol numbers 853 and 4235270918 , ID 000562).

\section{Sample collection}

For the in vitro study, mites from an approximately six-month-old female pit bull dog from the city of Niterói, in the Brazilian state of Rio de Janeiro were collected. It had been diagnosed for the first time with Demodex sp., presented a high parasite load, and had not previously been treated with any ectoparasiticide. Only one patient was used in order to minimize individual differences between mites, a procedure followed in other studies with similar objectives to this (Walton et al., 2004; Tighe et al., 2013). 
Mites were collected from the lesions by using adhesive tapes (Zhao et al., 2006, 2011; Pereira et al., 2012). The tapes, measuring $6 \times 2.5 \mathrm{~cm}$, were then adhered to microscopy slides and observed under light microscopy at magnifications of $100 \times$ and $400 \times$. As the collection of equivalent samples is difficult to be performed, given the uneven distribution of the mite population on the skin, it was not possible to standardize for a single number of mites per slide. Thus, slides that contained between 5 and 7 adult mites, evidently mobile, were chosen for the test. As in previous studies, the evident movement of chelicerae and tarsi was the criterion of choice for selecting viable samples (Gao et al., 2005; Tighe et al., 2013). Twenty seven samples were selected and distributed in triplicates (seven concentrations of the oil and two controls, positive and negative). In order to make the total of mites equal in each triplicate, this distribution rendered each replica with a difference of one or two mites in relation to the other two.

Some of the collected mites were fixed in $70 \%$ alcohol and sent to the Fundação Oswaldo Cruz for taxonomic identification. The mites were identified according to the key proposed by Domrow (1991).

\section{Analysis of the test product}

The chemical composition of the tea tree oil employed (Laszlo Aromaterapia, Belo Horizonte, Brazil) was analyzed by gas chromatography. The qualitative and quantitative analyses were both performed in a high-resolution gas chromatograph (7820A; Agilent, Santa Clara, CA, USA), equipped with a flame ionization detector and a $30 \mathrm{~m} \times 0.32 \mathrm{~mm} \times 0.25 \mathrm{~mm}$ column (HP-5; Agilent), at an initial temperature of $70^{\circ} \mathrm{C}$, the temperature being increased at a rate of $3^{\circ} \mathrm{C} / \mathrm{min}$ until reaching $240^{\circ} \mathrm{C}$. The injector and flame ionization detector were operated at $250^{\circ} \mathrm{C}$ and $260^{\circ} \mathrm{C}$, respectively. Hydrogen was used as a carrier gas, at a flow rate of $3 \mathrm{~mL} / \mathrm{min}$, and the split ratio was 1:30. The oil was diluted with chloroform (1\%), and $1 \mu \mathrm{L}$ was injected into the chromatograph. The components of the oil were identified by comparing their mass spectra with the Kovats retention index. Data were acquired and processed with EZChrom Elite Compact software, version A.04.05 (Agilent).

\section{Experimental procedures}

The 27 samples selected were divided into three groups: TTO $(n=21)$, to be treated with tea tree oil; AMZ $(n=3)$ to be treated with the amitraz solution (Triatox; MSD Saúde Animal, São Paulo, Brazil); and JBS $(n=3)$, to be treated with Johnson's Baby Shampoo (Johnson \& Johnson, Sao Paulo, Brazil), in its original factory concentration. The tapes were carefully detached from the microscopy slides, and $200 \mu \mathrm{L}$ of the respective substances were applied, covering the entire face of the glass slides. After the substances had been applied, the adhesive tapes with the samples were again placed onto the slides.

For the TTO group, the samples were divided into seven subgroups ( $\mathrm{n}=3$ samples/subgroup), in which the test product was applied in pure form and in six different dilutions: 50.0\%, 25.0\%, 12.5\%, 6.25\%, 5.0\% and 3.13\%. The shampoo used in the tea tree oil dilutions was the same as that used in the JBS group. In the AMZ (positive control) group, all three samples were treated with a solution of $4 \mathrm{ml}$ of $12.5 \%$ amitraz diluted in $1 \mathrm{~L}$ of water (a final solution of $0.05 \%$ amitraz, or $50 \mathrm{ppm}$ ). This ratio is recommended by the manufacturer when used in therapeutic baths of animals suffering from mange (Viana, 2014). In the JBS (negative control) group, all three samples were treated with the neutral shampoo in its original concentration, as used in the dilution of the tea tree oil. All dilutions were prepared at the time of use.

\section{Microscopy}

The samples were observed under microscopy, the parameters of interest being mite mobility and changes in aspects of mite bodies. The initial observations were made at magnifications of 100x, following a zigzag line, for $5 \mathrm{~min}$ and at 5-min intervals thereafter, until the death of each mite was suspected, after which a magnification of $400 \times$ was employed, and the chelicerae and tarsi of the mites were observed continuously for 60 s. The mobility (or lack thereof) of those structures over time attested to whether a mite was alive or dead (Gao et al., 2005; Tighe et al., 2013). The survival time was defined by the lapse of time between the application of the solution and the moment when the movement of the last mite in the sample ceased. Therefore, the time at which the last mite in each sample died was recorded was considered the total time required for the extermination of the mites in the sample and concentration in question. The same procedure was followed for all mites in each sample. At 30 min after confirmation of the last death, another confirmatory reading was taken. 
The temperature and relative humidity in the laboratory were measured at 60-min intervals with a thermo-hygrometer (Incoterm, Porto Alegre, Brazil).

\section{Results}

The mites were identified as $D$. canis and were deposited in the Entomological Collection of the Fundação Oswaldo Cruz, Registration numbers ACA - 4242, 4243 and 4244.

The compounds identified and quantified in the tea tree oil are shown in Table 1. Gas chromatography revealed that the tea tree oil used in this study had concentrations of $45.9 \%$ for terpinen-4-ol and $1.6 \%$ for 1,8 -cineol.

In the TTO group samples, after application, the deaths occurred between 4 and $214 \mathrm{~min}$. (Table 2). Mite agitation and opisthosomal wrinkling (Figure 1) were observed when the samples came into contact with the tea tree oil, especially at higher concentrations. Immediately before the death of each mite, there was progressive slowing of the movements of the chelicerae and tarsi.

In the AMZ group samples, the deaths, after application of the product, occurred between 268 and 434 min. (Table 2), and in the JBS group samples, the survival time was between 436 and 540 minutes (Table 2).

Table 1. Chemical constituents and their proportions in the tea tree oil used in the in vitro study against Demodex canis mites.

\begin{tabular}{cccc}
\hline Peak & RI & Constituent & \% \\
\hline 1 & 989 & a-pinene & 3.0 \\
2 & 1034 & a-terpinene & 5.7 \\
3 & 1039 & p-cymene & 2.7 \\
4 & 1042 & Limonene & 1.6 \\
5 & 1043 & 1 -8-cineole & 19.0 \\
6 & 1064 & y-terpinene & 2.6 \\
7 & 1086 & Terpinolene & 45.9 \\
9 & 1168 & Terpinen-4-ol & 6.4 \\
10 & 1184 & a-terpineol & 1.2 \\
11 & 1426 & B-gurjunene & 0.6 \\
& 1486 & Humulene & 0.1 \\
\end{tabular}

$\mathrm{RI}=$ retention index.

Table 2. Results of in vitro test of Demodex canis mites, in contact with different treatments.

\begin{tabular}{ccccc}
\hline & \multicolumn{4}{c}{ Mean time to last mite death (minutes) } \\
\cline { 2 - 5 } Treatment & Min. & Max. & Mean (standard deviation) & $\begin{array}{c}\text { Coeficient of } \\
\text { variation (\%) }\end{array}$ \\
\hline Amitraz at 0.05\% & 268 & 434 & $333.33(88.46)$ & 26.5 \\
Neutral shampoob & 436 & 540 & $470.67(60.04)$ & 12.8 \\
Tea tree oil at full strength & 4 & 10 & $8.00(3.46)$ & 43.3 \\
Tea tree oil at 50.0\% & 8 & 18 & $13.33(5.03)$ & 37.7 \\
Tea tree oil at 25.0\% & 10 & 14 & $12.00(2.00)$ & 16.7 \\
Tea tree oil at 12.5\% & 24 & 40 & $33.33(8.33)$ & 25.0 \\
Tea tree oil at 6.25\% & 80 & 134 & $98.67(30.62)$ & 31.0 \\
Tea tree oil at 5.0\% & 40 & 184 & $88.33(82.85)$ & 93.8 \\
Tea tree oil at 3.13\% & 44 & 214 & $100.67(98.15)$ & 97.5 \\
\hline
\end{tabular}

aPositive control (Triatox); bNegative control (Johnson's baby shampoo). 


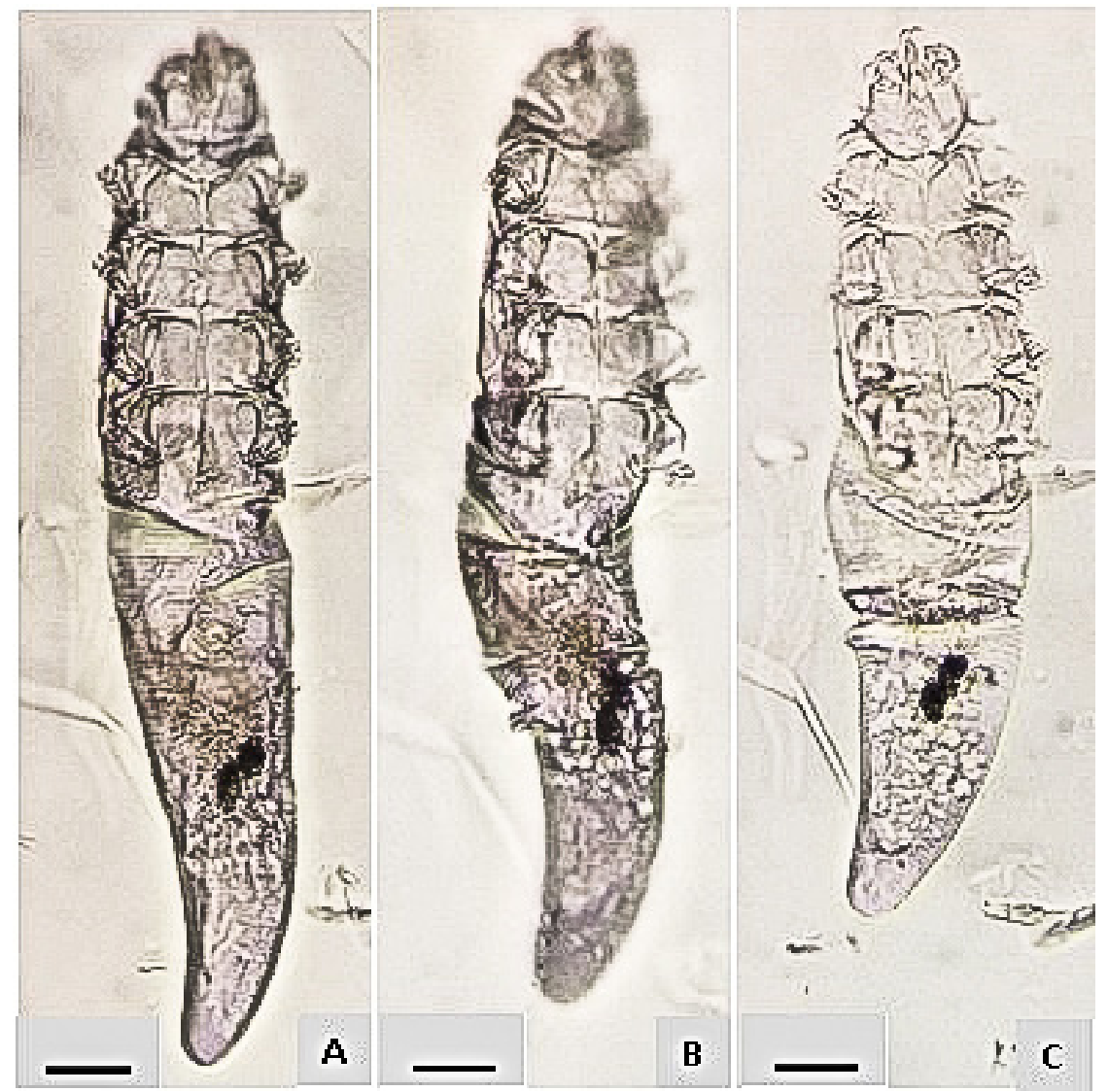

Figure 1. Specimens of Demodex canis, female, in the in vitro test: (A) live mite; (B) initial opisthosomal wrinkling, immediately after contact with pure tea tree oil (100\%); and (C) dead mite, with complete wrinkling of the opisthosoma and clarification of the opisthosomal cuticle, 6 min after contact with the oil (bar in A-C = $20.92 \mu \mathrm{m}$ ).

The lowest mortality time observed in the AMZ group (268 minutes) was higher than the maximum time detected in the TTO group with the lowest concentration tested (214 minutes) (Table 2). Although it was observed that the higher the concentration in the TTO group, the shorter the mite survival time was, in the concentration of $25 \%$ the death time of the last parasite was 14 minutes and in the $50 \%$ concentration it was 18 minutes (Table 2). With the exception of the $25 \%$ and $12,5 \%$ treatment, all others had greater variability than that observed in the AMZ group. A high variation between replicates (Table 2 ) occurred mainly between treatments with lower oil concentrations (5\% and 3.13\%).

There was no high variation in the temperature and humidity of the laboratory during the experiment. The average temperature was $26.4^{\circ} \mathrm{C}$ (range: $23.0-27.1^{\circ} \mathrm{C}$ ), and the average relative humidity was approximately $70 \%$ (range: 67-73\%).

\section{Discussion}

Gas chromatography showed that the commercial quality of the tea tree oil used in the present study was within the standards established by the ISO 4730:2004 and AS 2782-2009 (Silva et al., 2002; Simões et al., 2002; Walton et al., 2004; Mondello et al., 2006; Malhi et al., 2017).

In vitro, tea tree oil was effective against Demodex canis mites, being most efficient, in terms of its speed, at higher concentrations. As the evidence showed, a higher concentration was efficient in a shorter time and, conversely, a lower concentration required a longer time for an acaricidal effect to be achieved in the entire sample. Our data are consistent with the reports of Gao et al. (2005) concerning the effects of melaleuca oil on Demodex folliculorum Simon (1842), wherein the authors found concentration-and-time-dependent increases in mortality. Although the results of time of death between the $25 \%$ and $50 \%$ concentration groups were inverse to what was expected, the values are very close. This suggests that the time of death is dose-dependent, but the in interval between $25 \%$ and $50 \%$ not much difference should occur. This hypothesis deserves to be better analyzed in future investigations. 
In another study, Zhao et al. (2006) found that eucalyptus oil, from the same family as the Melaleuca alternifolia, was a potent acaricide with concentration-and-time-dependent increases in mortality of Demodex folliculorum and Demodex brevis Akbulatova (1963). These authors found that the eucalyptus oil was least effective in killing the mites with a concentration of $6.25 \%$, whereas the most suitable, effective concentration for the in vitro killing of these mites was $12.5 \%$. In the present study, even in the low dilutions tested $(3.13 \%, 5.0 \%$ and $6.25 \%)$, the velocity of killing mites was considerably faster than the AMZ group, and the concentration $25 \%$ showed the lowest variability (CV $=16.7 \%)$ in relation to the other concentrations of the TTO group, suggesting a more homogeneous action in the elimination of the mite. The agitation of mites soon after contact with tea tree oil, as well as the reduction in their mobility thereafter, is also similar to what was found by Zhao et al. (2006). It is possible that the action of these two oils may be similar, since Eucalyptus and Melaleuca, although with different chemical concentrations, have some similar chemical components (Noumi et al., 2011).

Although it is believed that the antiparasitic action of tea tree oil is attributable to terpinen-4-ol, the mechanism by which these constituents promote the death of Demodex mites has yet to be elucidated (Tighe et al., 2013). However, tea tree oil could disrupt various membrane structures of bacteria, fungi, protozoa, and enveloped viruses (Low et al., 2017; Lam et al., 2018). Mills et al. (2004) suggested that tea tree oil competitively blocks the neurotransmitter terminating enzyme acetylcholinesterase in parasites and may contribute to the arthropodicidal effect. However, it has been suggested that the inhibition of acetylcholinesterase by tea tree oil may be more potent than that of the primary monoterpenoid constituents, because of the synergistic or additive effect of a combination of components instead of a one single strong inhibitor (Miyazawa \& Yamafuji, 2006). Furthermore, another in vitro study showed that terpinen-4-ol can decrease the production of pro-inflammatory cytokines such as interferon gamma, interleukin IL-1 $\beta$, IL-6, and IL-17, as well as that of anti-inflammatory cytokines such as IL-4 and IL-10 (Nogueira, 2013).

The efficacy in vitro acaricidal action of tea tree oil was also reported by Walton et al. (2004) and Neves et al. (2013), both of whom used it at a concentration of 5\% against mites of the species Sarcoptes scabiei De Geer, 1778 and Otodectes cynotis (Hering, 1838), respectively.

Walton et al. (2004), Gao et al. (2005) and Yang et al. (2013) also conducted in vivo studies of tea tree oil, all showing that it had efficacious acaricidal action against various species of mites in a variety of hosts. According to those authors, the cumulative acaricidal, antibacterial, antipruritic, anti-inflammatory, and wound-healing effects of tea tree oil may have the potential to successfully reduce the burden of scabies infection and associated bacterial complications. The same mechanisms are believed to be involved in the effects of tea tree oil as a treatment for human ocular demodicosis (Gao et al., 2005; Tighe et al., 2013). Therefore, it is likely that these mechanisms would act on canine demodicosis in its natural environment.

In this study, amitraz was chosen as the positive control because it is a topical agent and could therefore be compared directly to the tea tree oil, which is also applied topically. It is noteworthy that the maximum time for mite mortality was longer in the AMZ group samples than in the TTO group samples. However, AMZ showed less variation between replicates.

Although neutral shampoo has no proven acaricidal action, the mites in the JBS group samples also died over time. That was likely due to desiccation and lack of nutrition, as remaining between the slide and the coverslip eventually led to dehydration and a natural difficulty in surviving away from the skin of the host. Gao et al. (2005) and Tighe et al. (2013) also reported that the controls had no acaricidal action, when observed for up to 150 minutes.

In the present study, the mites were observed in vitro, arranged on microscopy slides, and submitted to average temperatures of $26.4^{\circ} \mathrm{C}$ at $70 \%$ humidity. The suitable development temperature range, previously described for Demodex folliculorum, was $20-30^{\circ} \mathrm{C}$, of which the most suitable temperature range was $25-26^{\circ} \mathrm{C}$ (Zhao et al., 2005 , 2009). The authors did not evaluated the extreme temperatures, because it was not the aim of this study, but the average temperature of 26.4 seems to be suitable for this species, considering the maintenance of structural integrity and movements on the neutral shampoo group. It was not possible to report the acaricidal effects of melaleuca oil on Demodex canis mite directly on the skin of the dogs, especially considering that the mite insertion environment would be substantially different.

\section{Conclusions}

Tea tree oil, at any concentration, appears to have satisfactory acaricidal effects on mites of the species Demodex canis in vitro. In addition, the acaricidal effects of tea tree oil were faster than were those of amitraz. 


\section{Acknowledgements}

The authors thank Ingrid Benevides Machado, researcher at the National Reference Laboratory in Rickettsial Vectors, Oswaldo Cruz Institute, Oswaldo Cruz Foundation (Laboratório de Referência Nacional em Vetores das Riquetsioses do Instituto Oswaldo Cruz, Fundação Oswaldo (ruz), who made the identification of the mites, under the supervision of Gilberto Salles Gazêta, Coordinator and veterinary doctor, with experience in taxonomy and arthropod transmitted disease, mainly Acari. This work received financial support from the Brazilian Coordenação de Aperfeiçoamento de Pessoal de Nível Superior (CAPES, Office for the Advancement of Higher Education), Financiadora de Estudos e Projetos (Finep, Financing Agency for Studies and Projects), and Conselho Nacional de Desenvolvimento Científico e Tecnológico (CNPq, National Council for Scientific and Technological Development), as well as from the Fundação Carlos Chagas Filho de Amparo à Pesquisa do Estado do Rio de Janeiro (FAPERJ, Carlos Chagas Filho Foundation for the Support of Research in the State of Rio de Janeiro).

\section{References}

Adams HR. Farmacologia e terapêutica em veterinária. Rio de Janeiro: Editora Guanabara Koogan; 2003.

Arsenović M, Pezo L, Vasić N, Ćirić R, Stefanović M. The main factors influencing canine demodicosis treatment outcome and determination of optimal therapy. Parasitol Res 2015; 114(7): 2415-2426. http://dx.doi.org/10.1007/s00436-015-4543-7. PMid:26013574.

Barretto MLM, Ferreira ADD, Pascoal IC, Da Silva MBG, De Torres SM, Falcão MVD, et al. Amitraz: pharmacological and toxicological aspects in animals. Med Vet 2017; 11(3): 185-191. http://dx.doi.org/10.26605/medvet-n3-1792.

Beugnet F, Halos L, Larsen D, de Vos C. Efficacy of oral afoxolaner for the treatment of canine generalised demodicosis. Parasite 2016; 23: 14. http://dx.doi.org/10.1051/parasite/2016014. PMid:27012161.

Caldefie-Chézet F, Guerry M, Chalchat JC, Fusillier C, Vasson MP, Guillot J. Anti-inflammatory effects of Melaleuca alternifolia essential oil on human polymorphonuclear neutrophils and monocytes. Free Radic Res 2004; 38(8): 805-811. http://dx.doi.org/1 0.1080/1071576042000220247. PMid:15493453.

Castro KNC, Canuto KM, Brito ES, Costa-Júnior LM, Andrade IM, Magalhães JA, et al. In vitro efficacy of essential oils with different concentrations of 1,8-cineole against Rhipicephalus (Boophilus) microplus. Rev Bras Parasitol Vet 2018; 27(2): 203-210. http://dx.doi. org/10.1590/s1984-296120180015. PMid:29846446.

Delayte EH, Otsuka M, Larsson CE, Castro RCC. Eficácia das lactonas macrocíclicas sistêmicas (ivermectina e moxidectina) na terapia da demodicidose canina generalizada. Arq Bras Med Vet Zootec 2006; 58(1): 31-38. http://dx.doi.org/10.1590/S010209352006000100006.

Domrow R. Acari Prostigmata (excluding Trombiculidae) parasitic on Australian vertebrates: an annotated checklist, keys and bibliography. Invertebr Syst 1991; 4(6): 1283-1376. http://dx.doi.org/10.1071/IT9901283.

Fourie JJ, Liebenberg JE, Horak IG, Taenzler J, Heckeroth AR, Frénais R. Efficacy of orally administered fluralaner (Bravecto ${ }^{\mathrm{TM}}$ ) or topically applied imidacloprid/moxidectin (Advocate $\left.{ }^{\circledR}\right)$ against generalized demodicosis in dogs. Parasit Vectors 2015; 8(1): 187. http://dx.doi.org/10.1186/s13071-015-0775-8. PMid:25881320.

Gaens D, Rummel C, Schmidt M, Hamann M, Geyer J. Suspected neurological toxicity after oral application of fluralaner (Bravecto ${ }^{8}$ ) in a Kooikerhondje dog. BMC Vet Res 2019; 15(1): 283. http://dx.doi.org/10.1186/s12917-019-2016-4. PMid:31391054.

Gao YY, Di Pascuale MA, Li W, Baradaran-Rafii A, Elizondo A, Kuo CL, et al. In vitro and in vivo killing of ocular Demodex by tea tree oil. Br J Ophthalmol 2005; 89(11): 1468-1473. http://dx.doi.org/10.1136/bjo.2005.072363. PMid:16234455.

Gortel K. Update on canine demodicosis. Vet Clin Small North Am Small Anim Pract 2006; 36(1): $229-241$.

Hugnet C, Buronrosse F, Pineau X, Cadoré JL, Lorgue G, Berny PJ. Toxicity and kinetics of amitraz in dogs. Am J Vet Res 1996; 57(10): 1506-1510. PMid:8896693.

Jarmuda S, O'Reilly N, Żaba R, Jakubowicz O, Szkaradkiewicz A, Kavanagh K. Potential role of Demodex mites and bacteria in the induction of rosacea. J Med Microbio/ 2012; 61(Pt 11): 1504-1510. http://dx.doi.org/10.1099/jmm.0.048090-0. PMid:22933353.

Lam NS, Long XX, Griffin RC, Chen MK, Doery JC. Can the tea tree oil (Australian native plant: Melaleuca alternifolia Cheel) be an alternative treatment for human demodicosis on skin? Parasitology 2018; 145(12): 1510-1520. http://dx.doi.org/10.1017/ S0031182018000495. PMid:29667560.

Low WL, Kenward K, Britland ST, Amin MC, Martin C. Essential oils and metal ions as alternative antimicrobial agents: a focus on tea tree oil and silver. Int Wound J 2017; 14(2): 369-384. http://dx.doi.org/10.1111/iwj.12611. PMid:27146784. 
Malhi HK, Tu J, Riley TV, Kumarasinghe SP, Hammer KA. Tea tree oil gel for mild to moderate acne; a 12 week uncontrolled, open-label phase II pilot study. Australas J Dermato/ 2017; 58(3): 205-210. http://dx.doi.org/10.1111/ajd.12465. PMid:27000386.

Mills C, Cleary BJ, Gilmer JF, Walsh JJ. Inhibition of acetylcholinesterase by tea tree oil. J Pharm Pharmacol 2004; 56(3): 375-379. http://dx.doi.org/10.1211/0022357022773. PMid:15025863.

Miyazawa M, Yamafuji C. Inhibition of acetylcholinesterase activity by tea tree oil and constituent terpenoids. Flavour Fragr J 2006; 21(2): 198-201.

Mondello F, De Bernardis F, Girolamo A, Cassone A, Salvatore G. In vivo activity of terpinen-4-ol, the main bioactive component of Melaleuca alternifolia Cheel (tea tree) oil against azole-susceptible and -resistant human pathogenic Candida species. BMC Infect Dis 2006; 6(1): 158. http://dx.doi.org/10.1186/1471-2334-6-158. PMid:17083732.

Mueller RS, Bensignor E, Ferrer L, Holm B, Lemarie S, Paradis M, et al. Treatment of demodicosis in dogs: 2011 clinical practice guidelines. Vet Dermato/ 2012; 23(2): 86-e21, e20-e21. http://dx.doi.org/10.1111/j.1365-3164.2011.01026.x. PMid:22329600.

Nazzaro F, Fratianni F, De Martino L, Coppola R, De Feo V. Effect of essential oils on pathogenic bacteria. Pharmaceuticals 2013; 6(12): 1451-1474. http://dx.doi.org/10.3390/ph6121451. PMid:24287491.

Neves RCSM, Ferraz RHS, Mendonça AJ, Lima SR, Cruz FAZ, Rosa JG, et al. Teste in vitro do efeito acaricida do óleo essencial de Melaleuca alternifolia sobre Otodectes cynotis. R Bras Ci Vet 2013; 20(1): 9-12.

Neves RCSM, Makino H, Cruz TP, Silveira MM, Sousa VR, Dutra V, et al. In vitro and in vivo efficacy of tea tree essential oil for bacterial and yeast ear infections in dogs. Pesq Vet Bras 2018; 38(8): 1597-1607. http://dx.doi.org/10.1590/1678-5150-pvb-5055.

Nogueira MNM. Caracterização da ação modulatória de citocinas inflamatórias pelo óleo de Melaleuca alternifolia e seus componentes (terpinen-4-ol e alfa-terpineol) em macrófagos humanos ativados pelo lipopolissacarídeos de Porphyromonas gingivalis Escherichia coli. [dissertação]. São Paulo: Universidade Estadual Paulista; 2013.

Noumi E, Snoussi M, Hajlaoui H, Trabelsi N, Ksouri R, Valentin E, et al. Chemical composition, antioxidant and antifungal potential of Melaleuca alternifolia (tea tree) and Eucalyptus globulus essential oils against oral Candida species. J Med Plants Res 2011; 5(17): 4147-4156.

Patra G, Behera P, Ghosh S, Mohanta D, Borthakur SK, Biswas P, et al. Molecular Characterization of Chitin Synthase Gene of Demodex canis from Mizoram, India. Acta Parasitol 2019; 64(1): 57-62. http://dx.doi.org/10.2478/s11686-018-00008-6. PMid:30645735.

Perego R, Spada E, Foppa C, Proverbio D. Critically appraised topic for the most effective and safe treatment for canine generalised demodicosis. BMC Vet Res 2019; 15(1): 17. http://dx.doi.org/10.1186/s12917-018-1767-7. PMid:30616591.

Pereira AV, Pereira SA, Gremião IDF, Campos MP, Ferreira AMR. Comparison of acetate tape impression with squeezing versus skin scraping for the diagnosis of canine demodicosis. Aust Vet J 2012; 90(11): 448-450. http://dx.doi.org/10.1111/j.17510813.2012.00994.x. PMid:23106326.

Puvača N, Cabarkapa I, Petrovic A, Bursic V, Prodanovic R, Solesa D, et al. Tea tree (Melaleuca alternifolia) and its essential oil: antimicrobial, antioxidant and acaricidal effects in poultry production. Worlds Poult Sci J 2019; 75(2): 235-246. http://dx.doi. org/10.1017/S0043933919000229.

Rhodes KH. Demodicosis. In: Rhodes KH, Werner AH, editors. The 5-minute veterinary consult clinical companion: small animal dermatology. Philadelphia: Lippincott Williams \& Wilkins; 2004. p. 203-209.

Rohdich N, Roepke RK, Zschiesche E. A randomized, blinded, controlled and multi-centered field study comparing the efficacy and safety of Bravecto ${ }^{\mathrm{TM}}$ (fluralaner) against Frontline ${ }^{\mathrm{TM}}$ (fipronil) in flea- and tick-infested dogs. Parasit Vectors $2014 ; 7(1): 83$. http://dx.doi.org/10.1186/1756-3305-7-83. PMid:24593931.

Savla K, Le JT, Pucker AD. Tea tree oil for Demodex blepharitis. Cochrane Syst Rev 2019; 6. https://doi.org/10.1002/14651858. CD013333.

Silva SRS, Demuner AJ, Barbosa LC, Casali VWD, Nascimento EA, Pinheiro AL. Efeito do estresse hídrico sobre características de crescimento e a produção de óleo essencial de Melaleuca alternifolia Cheel. Acta Scientiarum 2002; 24(5): $1363-1368$.

Simões RP, Groppo FC, Sartorato A, Del Fiol FS, Mattos Filho TR, Ramacciato JC, et al. Efeito do óleo de Melaleuca alternifolia sobre a infecção estafilocócica. Rev Lecta 2002; 20(2): 143-152.

Singh SK, Kumar M, Jadhav RK, Saxena SK. An update on therapeutic management of Canine Demodicosis. Vet World 2011; 4(1): 41-44. http://dx.doi.org/10.5455/vetworld.2011.41-44.

Six RH, Becskei C, Mazaleski MM, Fourie J, Mahabir SP, Myers MR, et al. Efficacy of sarolaner, a novel oral isoxazoline, against two common mite infestations in dogs: Demodex spp. and Otodectes cynotis. Vet Parasito/ 2016; 222: 62-66. http://dx.doi.org/10.1016/j. vetpar.2016.02.027. PMid:26971196. 
Snyder DE, Wiseman S, Liebenberg JE. Efficacy of lotilaner (Credelio ${ }^{\mathrm{TM}}$ ), a novel oral isoxazoline against naturally occurring mange mite infestations in dogs caused by Demodex spp. Parasit Vectors 2017; 10(1): 532. http://dx.doi.org/10.1186/s13071-017-2472-2. PMid:29089049.

Tighe S, Gao YY, Tseng SCG. Terpinen-4-ol is the most active ingredient of tea tree oil to kill Demodex mites. Trans/ Vis Sci Technol 2013; 2(7): 2. http://dx.doi.org/10.1167/tvst.2.7.2. PMid:24349880.

Viana FAB. Guia terapêutico veterinário. 3rd ed. Lagoa Santa: Gráfica e Editora Cem; 2014.

Walton SF, McKinnon M, Pizzutto S, Dougall A, Williams A, Currie BJ. Acaricidal activity of Melaleuca alternifolia (tea tree) oil: in vitro sensitivity of Sarcoptes scabiei var hominis to terpinen-4-ol. Arch Dermato/ 2004; 140(5): 563-566. http://dx.doi.org/10.1001/ archderm.140.5.563. PMid:15148100.

Yang JV, Cho KS, Chung NH, Kim CH, Suh JW, Lee HS. Constituents of volatile compounds derived from Melaleuca alternifolia leaf oil and acaricidal toxicities against house dust mites. J Korean Soc App/ Biol Chem 2013; 56(1): 91-94. http://dx.doi.org/10.1007/ s13765-012-2195-1.

Zhao Y, Guo N, Li C, Li X. Effect of Oleum Eucalypti on Demodex in vitro. Chin J Vec Biol Cont 2006; 17(6): $461-464$.

Zhao Y, Guo N, Zheng X, Yang S, Zhang M, Zhang L, et al. Observations on morphology and the survival temperature range of Demodex folliculorum. Acta Entomol Sin 2005; 48(5): 754-758.

Zhao YE, Guo N, Wu LP. Influence of temperature and medium on viability of Demodex folliculorum and Demodex brevis (Acari: demodicidae). Exp App/ Acarol 2011; 54(4): 421-425. http://dx.doi.org/10.1007/s10493-011-9445-5. PMid:21479960.

Zhao YE, Guo N, Wu LP. The effect of temperature on the viability of Demodex folliculorum and Demodex brevis. Parasitol Res 2009; 105(6): 1623-1628. http://dx.doi.org/10.1007/s00436-009-1603-x. PMid:19774398.

Zulkarnain I, Agusni RI, Hidayati AN. Comparison of Tea Tree oil 5\% Cream, Tea Tree Oil 5\%+ Permethrin 5\% Cream, and Permethrine 5\% Cream in Child Scabies. Int J Clin Exp Med Sci 2019; 4(6): 87-93. 